\title{
НОВА ИСТОРИЈА И/ИЛИ АПОЛОГИЈА ИМПЕРИЈЕ
}

Као допринос истраживању сложених питања историје европских држава, у маниру синтезе социолошке историје, историје елита и историје институција, објављена је монографија Хабзбуршко ияарство. Нова историја (The Habsburg Empire. A New History, Cambridge Massachusetts: the Belknap Press of Harvard University press, 2016), ayтора Питера М. Џудсона (Pieter M. Judson), професора на Департману за историју и цивилизацију Европског универзитетског института (European University Institute; Department of History and Civilization), чија је ужа област научног интересовања историја средње, источне и југоисточне Европе у XIX и XX веку.

Књига следи начело дугог трајања, те је предност даิта процесима, док су чињенице коришћене првенствено да би се процес објаснио, не да би се пружила потпуна фактографска слика сагледаног периода. Нова историја се односи на нови приступ сагледавању питања односа структура царства и односа тих структура према спољном свету. Џудсон није покушавао да прескаче појединачне догађаје, али је радије пружио опис процесаิ који су обликовали политичку и економску историју Хабзбуршке Монархије 1740-1918 године. Како саิм наводи, жижа истраживачког интересовања задржана је на империји као таквој, уз посматрање језичко-националних група унутар ње. Питања која аутор обрађује, у првом реду однос центра и периферије, питање империје и националне државе, државе и/или територије, могу се разумети и као питања дебатног карактера, а ауторово настојање да рпужи нове погледе на познате чињенице, на тренутке прелази у тежњу за ревизијом. Сама чињеница да је Хабзбуршка Монархија опстала тако дуго, а да у периоду који је Џудсон обрадио, није постигла ниједну убедљиву победу, ни на бојном ни на дипломатском пољу, већ саิма представља, истовремено, успех и парадокс, којима је историја Дунавске монархије обележена.

Структуру монографије чини осам поглавља: The Accidental Empire (Неочекивано царство); Servants and Citizens - Empire and Fatherland 1780-1815 (Поданици и грађани - царство и отаџбина 17801815); An Empire of Contradictions 1815-1848 (Царство супротности 1815-1848); Whose Empire? The Revolutions of 1848-1849 (Чије царство? Револуције 1848-1849); Mid-Century Modern: the Emergence of a Liberal Empire (Модерност средином века: настанак либералног царства); Culture Wars and Wars for Culture (Културни ратови и ратови за културу); Everyday Empire, Our Empire 1880-1914 (Свакодневица царства - Наше царство 1880-1914); War and Radical State-Building 1914-1925 (Рат и радикална изградња нових држава 1914-1925); са Уводом (Introduction) и списком географских и личних имена (Note on Names and Places) и списком карата и илустрација (List of Maps and Illustrations) испред и Закључком (Epilogue: The New Empires),

1 Pieter M. Judson, The Habsburg Empire. A New History, Cambridge Massachusetts: the Belknap Press of Harvard University press, 2016. 
напоменама (Notes), захвалницом (Acknowledgements) и индексима (Index) иза основног текста монографије. Свако поглавље је подељено на више потпоглавља.

Аутор је студију засновао на великом броју извора и литературе, на начин који читаоца води кроз нове интерпретације, идеје погледе на позната места историје Хабзбуршке Монархије, праћене ауторовим закључцима и проценом узрока успона и пада династије и државе Хабзбурга. Концепт књиге тече уобичајеним правцем и нуди поднаслове који интригирају читаоце. Поглавља су сложена у хармоничну целину, подељена су хронолошки, а граничне године омеђују важне периоде у историји Монархије. Џудсон се са успехом носи са процесом сазнавања и закључивања суштине историје XVIII века, кроз анализу процеса интеграције Хабзбуршке Монархије из конгломерата територија у јединствено државно тело, што је изискивало и тешке административне задатке, због којих је Монархија каснила за Француском, Британијом и Пруском. Већ у Уводу, наглашено да је компликована терминологија морала бити савладана у односу на одређивање оквира Монархије као и претходнике који су се бавили проучавањем њене историје. На примеру избора 1911. године, описане су све различитости и супротности Хабзбурешке Монархије.

Терезијанска и јосифинска ера је посебно анализирана. Аутор ту настоји да бројним примерима опише сву различитост живота на селу и у граду, као и економске проблеме и захтеве са којима се двор у Бечу суочавао, религиозним односима у држави, компликовану хијерархију, засновану на историјском праву. Овиме је аутор омогућио увид у сваки део историје Хабзбуршке Монархије у разматраном периоду. Кроз бројне примере, Џудсон пружа увид у чиниоце који су изнутра и споља утицали на изградњу апсолутизма у Хабзбуршкој Монархији. Као црвена нит се кроз читаву монографију провлачи питање односа између народаิ који су улазили у састав Хабзбуршке Монархије, са једне и државе, са друге стране. Политички национализам је третиран првенствено као производ односа империјалних структура и регионалних традиција. Поређење концепата империје и народне државе, које су у случају Хабзбуршке монархије испреплетене и, често на парадоксалан начин, међузависне, умногоме може послуижти као основа за изучавање како историје Хабзбуршке Монархије у целини, тако и националних историја њених народа.

Трансформација Монархије и ратови са Наполеоновом Француском, потом ера Метерниха и Револуција 1848-1849, описани су у првим поглављима. Насупрот периоду Коалиционих ратова (1792-1815), Метернихова ера (1815-1848) је време стабилизације државе, јачања трговинских и економских веза и, нарочито, сузбијања националних настојања широм државе. Борба Монархије за опстанак у Револуцији 1848-1849 и спас са стране, навели су Џудсона да поглавље наслови Чије Царство. Неколицином примера, анализирани су догађаји у Угарској, Хрватској, Италији, Галицији..., током револуционарних дешавања. Револуцију аутор посматра као догађај од суштинске важности за опстанак Монархије. Основна питања у којима сагледава Ре- 
волуцију, своде се на однос легитимизма и национализма. Само по себи, ово питање је већ доста сложено. Наредно поглавље, Настанак либерализаиије изарства, обрађује напоре Монархије да се прилагоди и трансформише. Кохерентни чинилац Монархије, тј. једини кохезивни фактор је, у овом случају, цар - нови, а показаће се и најдуговечнији - Фрања Јосиф (1848-1916). Он је својеврсни двоструки симбол: симбол спаса (1848) и симбол пропасти (1914-1918) Хабзбуршке Монархије. Монархија није успела да нађе решење за национално питање, иако је доба надзираног либерализма достигло високе културне, уметничке и научне домете, нарочито на пољу медицине, лигвистике и филологије, права...

Аустро-угарска Нагодба 1867. године је средина, компромис између историјског права и права на народно одређење. Аутор, на овом месту, међутим, нуди потпуно различит приступ овом питању у односу на друге сличне студије, кроз анализу интегративних чинилаца у погледу економског развоја, економске експанзије на Балкан, Бечког универзитета, великог броја уметника и научника који пружају (варљиву) слику стаблне и успешне земље. Није пропуштен ниједан сегмент друштвеног, културног, дневнополитичког живота при анализирању овог периода.

У поглављу Културни ратови и ратови за културу; Свакодневица изарства; Наше изарство 1880-1914, Џудсон оживљава деценије развоја Монархије, њена настојања да преобрази политички систем, борбу за опште право гласа, слободу штампе, нове залете у уметности и архитектури, унификацију градова и унапређење услова живота. У неколико примера, аутор Аустроугарску описује као земљу која, упркос националним супротностима, успешно опстаје у светском систему. Свакако, Аустроугарска у овом периоду јесте држава са статусом велике силе, али је она, уједно, најслабија велика сила, која све мање може да утиче на светскополитички развој, а све више преузима улогу „бриљантног секунданта“" Немачке.

Последња поглавља, Први светски рат и Рат и радикална изградња држава 1914-1925, као и Епилог - Нова ияарства, написана су јединственим начином. Рат је анализиран кроз анализу кључних особа и кучних одлука, грешака у војној стратегији, пораза на фронту, свакодневног живота и интензивирања националних покрета од 1917. године. Смрт Фрање Јосифа 21. новембра 1916. године, била симболични завршни удар на телу посрнуле и, већ извесно, урушене Монархије. Све јасније су изношени захтеви за потпуном реорганизацијом Монархије. До лета 1918. године, изнети су и захтеви за изградњом нових националних држава. Покрети владајућих елита Аустроугарске дошли су сувише касно да би ишта могли да учине у прилог одржања Двојне Монархије. Држава је урушена услед нерешеног националног питања, као и ниског ступња слободе јавне речи. Ово последње питање, једва да је било на нешто вишем нивоу и у свим новонасталим државама. Нове националне државе биле су, такође, ограничене бројним проблемима, наслеђеним или новонасталим. Хабзбршко цุарство. Нова историја је књига коју не би требало заобилазити при 

представља подстицај за размишљање и истраживање места националних историографија којих се ова комплексна питања тичу.

Алекса М. Поповић 